\title{
Correction to: Out of the woods: psychophysiological investigations on wood odors to estimate their suitability as ambient scents
}

\author{
Linda Schreiner ${ }^{1,2}$ (D) Brid Karacan ${ }^{2}$. Sonja Blankenagel ${ }^{2} \cdot$ Kai Packhaeuser $^{3}$. \\ Jessica Freiherr ${ }^{2,4,5} \cdot$ Helene M. Loos ${ }^{1,2}$ (D)
}

Published online: 11 December 2021

(c) The Author(s) 2021

\section{Correction to: Wood Science and Technology (2020) 54:1385-1400 https://doi.org/10.1007/s00226-020-01216-y}

The article [Out of the woods: psychophysiological investigations on wood odors to estimate their suitability as ambient scents], written by [Linda Schreiner, Brid Karacan, Sonja Blankenagel, Kai Packhaeuser, Jessica Freiherr and Helene M. Loos], was originally published Online First without Open Access. After publication in volume [54], issue [5], page [1385-1400] the author decided to opt for Open Choice and to make the article an Open Access publication. Therefore, the copyright of the article has been changed to (C) [The Author(s)] [2021] and this article is licensed under a Creative Commons Attribution 4.0 International License, which permits use, sharing, adaptation, distribution and reproduction in any medium or format, as long as you give appropriate credit to the original author(s) and the source, provide a link to the Creative Commons licence, and indicate if changes were made. The images or other third party material in this article are included in the article's Creative Commons licence, unless indicated otherwise in a credit line to the material. If

The original article can be found online at https://doi.org/10.1007/s00226-020-01216-y.

Helene M. Loos

helene.loos@ivv.fraunhofer.de

1 Chair of Aroma and Smell Research, Friedrich-Alexander-Universität Erlangen-Nürnberg (FAU), Henkestr. 9, 91054 Erlangen, Germany

2 Department of Sensory Analytics, Fraunhofer Institute for Process Engineering and Packaging (IVV), Giggenhauser Str. 35, 85354 Freising, Germany

3 Fraunhofer IIS, Fraunhofer Institute for Integrated Circuits, Am Wolfsmantel 33, 91058 Erlangen, Germany

4 Department of Psychiatry and Psychotherapy, Friedrich-Alexander-Universität Erlangen-Nürnberg, Erlangen, Germany

5 Diagnostic and Interventional Neuroradiology, RWTH Aachen University, Aachen, Germany 
material is not included in the article's Creative Commons licence and your intended use is not permitted by statutory regulation or exceeds the permitted use, you will need to obtain permission directly from the copyright holder. To view a copy of this licence, visit http://creativecommons.org/licenses/by/4.0/.

The original article has been corrected.

Funding note: Open Access funding enabled and organized by Projekt DEAL.

Open Access This article is licensed under a Creative Commons Attribution 4.0 International License, which permits use, sharing, adaptation, distribution and reproduction in any medium or format, as long as you give appropriate credit to the original author(s) and the source, provide a link to the Creative Commons licence, and indicate if changes were made. The images or other third party material in this article are included in the article's Creative Commons licence, unless indicated otherwise in a credit line to the material. If material is not included in the article's Creative Commons licence and your intended use is not permitted by statutory regulation or exceeds the permitted use, you will need to obtain permission directly from the copyright holder. To view a copy of this licence, visit http://creativecommons.org/ licenses/by/4.0/.

Open Access This article is licensed under a Creative Commons Attribution 4.0 International License, which permits use, sharing, adaptation, distribution and reproduction in any medium or format, as long as you give appropriate credit to the original author(s) and the source, provide a link to the Creative Commons licence, and indicate if changes were made. The images or other third party material in this article are included in the article's Creative Commons licence, unless indicated otherwise in a credit line to the material. If material is not included in the article's Creative Commons licence and your intended use is not permitted by statutory regulation or exceeds the permitted use, you will need to obtain permission directly from the copyright holder. To view a copy of this licence, visit http://creativecommons.org/ licenses/by/4.0/.

Publisher's Note Springer Nature remains neutral with regard to jurisdictional claims in published maps and institutional affiliations. 